\title{
A PREPONDERÂNCIA DA TROCA DE DÁDIVAS EM UMA PRISÃO DE MULHERES
}

\section{Leonardo Alves dos Santos}

Bacharel em Ciências Sociais pela Universidade Federal do Rio Grande do Norte, mestre em Antropologia Social pela Universidade Federal do Rio Grande do Norte. Doutorando no Programa de Pós-Graduação em Antropologia Social da Universidade de Brasília.

E-mail: leonardo.alves8@yahoo.com.br

\section{RESUMO}

Este texto é um dos resultados da dissertação de mestrado apresentada em março de 2015 sob o título "Emoção e Penalidade: Mulheres no Complexo Penal Dr. João Chaves". O objetivo do presente trabalho é tentar entender o porquê da preponderância da troca-dádiva no interior do pavilhão feminino do CPJC e a importância dessas trocas na organização e interação social das mulheres que lá residem. Dessa forma, se fez necessário recuperar a teoria de Marcel Mauss sobre o dom, assim como os desenvolvimentos posteriores realizados por outros autores. Para em seguida prosseguir com a descrição do campo pesquisado e de sua análise a luz das ideias previamente expostas, apresentando a tese da passagem da troca mercantilista do mercado à trocadádiva. Por fim, a conclusão sugere uma possível resposta para o domínio da troca de dádivas em relação a troca mercantilista dentro da ala feminina do Complexo Penal Dr. João Chaves.

Palavras-chave: Prisão. Mulher. Dádiva. 


\section{INTRODUÇÃO}

Este trabalho é uma tentativa de colocar no plano da escrita possíveis respostas às questões que se apresentaram após a elaboração da minha dissertação de mestrado (ALVES DOS SANTOS, 2015) fruto de uma pesquisa realizada entre os anos de 2013 e 2014, a qual foi conduzida através de entrevistas, observação participante e conversas guiadas no pavilhão feminino do Complexo Penal Dr. João Chaves em Natal, Rio Grande do Norte ${ }^{1}$. As questões, mencionadas acima, giravam em torno da importância da trocadádiva no interior do pavilhão, ainda que o tema da dádiva esteja presente na dissertação já citada, por questão de síntese e objetivo do trabalho alguns aspectos não foram abordados de maneira suficiente, é então o que pretendo desenvolver aqui ao tentar responder "o porquê da preponderância da troca-dádiva no interior do pavilhão feminino do CPJC".

O objetivo deste trabalho é entender a importância dessas trocas na organização e interação social das mulheres que lá residem. Para isso se faz necessário em um primeiro momento, recuperarmos a teoria de Marcel Mauss sobre o dom e os desenvolvimentos posteriores realizados por outros autores, mas que tiveram grande influência na minha interpretação dos fenômenos sociais observados durante a pesquisa de campo ${ }^{2}$. Em um segundo momento prossigo com uma breve contextualização do campo pesquisado e de sua análise a luz das ideias previamente expostas, expondo a tese da passagem da preponderância do mercado à troca-dádiva. Por fim, concluo apresentando uma possível resposta para o domínio da troca de dádivas em relação a troca mercantilista dentro da ala feminina do Complexo Penal Dr. João Chaves.

\section{ENTENDENDO A DÁDIVA: TEORIA E DESENVOLVIMENTOS}

Mauss apontou como sistema de prestações totais, o sistema gerado a partir de uma determinada forma de troca entre grupos ou pessoas, responsável pela criação dos vínculos sociais que as unem e organizam. Essas trocas são regidas através de três obrigações: dar, receber e retribuir. Segundo Mauss (1950/2003), damos algo a alguém

\footnotetext{
${ }^{1}$ Por motivos de síntese o nome poderá aparecer como CPJC ou João Chaves.

${ }^{2}$ Tentando evitar muita repetição textual a referência pode ser dom ou dádiva, ambos são usados com o mesmo sentido.
} 
porque confiamos que haverá retribuição, pois, a coisa dada (ou como ele chamou: o dom), carrega consigo aquele que dá, em uma mistura pessoa-coisa que faria o receptor lembrar constantemente que deve retornar ou passar adiante o item recebido. Neste tipo de troca não se troca somente bens materiais, mas imateriais, assim como não se troca somente com humanos, mas também com deuses e outros seres. Outro aspecto importante destacado pelo autor é que, segundo ele, o sistema de prestações totais pode aparecer também de forma agonística, na qual grupos ou pessoas se enfrentam através da destruição de suas riquezas. As prestações totais como descritas acima e a discussão sobre a troca de dádivas se tornaram o ponto de partida e a base para as reflexões teóricas deste ensaio.

Buscando ampliar a noção de dom, assim como também um melhor entendimento deste fenômeno como observado por Mauss (1950/2003), segui na leitura de alguns de seus debatedores e continuadores do seu legado. Um deles, a antropóloga Mary Douglas, argumenta em seu texto a não existência do dom gratuito "o que está errado com o chamado dom gratuito é a intenção do doador em ficar isento de presentes de retorno provenientes do destinatário. Recusando a quitação coloca o ato de dar, fora de quaisquer laços mútuos" (1990, p. 7). Ao recusar a retribuição, o doador, retira a sua intenção de estabelecimento de vínculo com aquele que recebeu o presente, logo se esvai da transação o caráter subjetivo, a força coisa-pessoa, residente no que foi dado e que impele a retribuição. "De acordo com Marcel Mauss, isto é o que está errado com o dom de graça. Um presente que não faz nada para melhorar a solidariedade é uma contradição" (DOUGLAS, 1990, p. 7).

O sociólogo Pierre Bourdieu foi outro grande intérprete da obra de Marcel Mauss, como será possível ver aqui, ele precedeu em anos, o que viria a ser os argumentos antiutilitaristas na interpretação das trocas de dádivas. Segundo Bourdieu (1996) a troca de dons reside em uma illusio, uma self deception individual e coletiva, pois "o dom só é de fato dom se não parecer como tal, nem para quem o faz nem para quem o recebe" (BOURDIEU, 1996, p.10), sua interpretação leva em conta três pontos fundamentais: 1) o tempo, o intervalo entre dom e contra-dom; 2) a incerteza na retribuição; 3) a teoria do agente e da ação, que toma como o princípio motivador da troca as disposições do habitus e não a consciência ou intenção do ator. Além de situar a dádiva em uma posição além da liberdade individual e da obrigação social, Bourdieu (1996) argumenta que as relações de força estabelecidas a partir deste tipo de vínculo se instauram e se perpetuam através do conhecimento e do reconhecimento, 
O que implica que ela só pode se realizar entre agentes capazes de se comunicar, de se compreender, ou seja, dotados dos mesmos esquemas cognitivos, e dispostos a comunicar-se, isto é, a reconhecer-se mutuamente como interlocutores legítimos, iguais em honra, a aceitar a interlocução, a estar in speaking terms (BOURDIEU, 1996, p.14).

Essa comunicação seria responsável pelas trocas de bens simbólicos, assim como da transmutação do capital econômico em capital simbólico. Outros aspectos importantes ainda aparecem na obra de Bourdieu como a interpretação da recusa da troca enquanto desonra e a de situar, ainda que superficialmente, o ciclo de vingança como uma forma de reciprocidade. Acredito que sua interpretação abarca todas as outras aqui descritas e que suas lacunas e insuficiências podem ser auxiliadas pelas teorias dos outros autores a serem mencionados.

Na mesma direção apontada por Douglas (1990) e Bourdieu (1996), Jacques Godbout e Allain Caillé, membros do Mouvement Anti-Utilitariste des Sciences Sociales ou MAUSS, vão focar na importância da construção dos laços sociais a partir da troca de dons, assim como pensar as relações da dádiva com o mercado e como os dois coexistem na contemporaneidade, uma vez que a relação mercadológica busca a quitação das dívidas, enquanto que a dádiva busca o endividamento, como ressalta Godbout (1998, p.3): "a liberdade moderna é, essencialmente, a ausência de dívida". Ainda segundo o autor, tal lógica causou uma inversão no modelo utilitarista de meios e fins, uma vez que o produto passa a ser o objetivo final, ao invés de meio para atingi-lo e "em nome da liberdade, acaba-se por submeter os indivíduos a um modelo mecânico e determinista que não deixa nenhum lugar para o inesperado" (GODBOUT, p.4).

Partindo das diferenças entre a dádiva e os dois paradigmas econômicos, o individualista e o holista, Godbout apresenta alguns desenvolvimentos importantes sobre a obrigação e a liberdade contidas nos vínculos sociais criados a partir da troca-dádiva. $\mathrm{O}$ principal deles, ao meu ver, é a tese de que as trocas de dádivas favoreceriam a criação de zonas de incerteza, de forma de que quanto mais incerta a retribuição maior a liberdade das partes envolvidas, o que transformaria o ato de retribuir no ato de dar, afastando-se para o mais longe possível da obrigação implícita na troca de dons. "O ator de um sistema de dádiva tende a manter o sistema num estado de incerteza estrutural, para permitir que a confiança se manifeste" (GODBOUT, 1998, p.8).

Outro interessante desenvolvimento realizado dentro do MAUSS encontra-se no livro de Mark R. Anspach, chamado "Anatomia da Vingança”, em seu texto, o autor 
esboça em plano analítico a passagem da reciprocidade negativa ao sacrifício e do sacrifício à reciprocidade do dom. Segundo o autor, tal movimento pacificador só pode ser feito graças a um ato violento em um terceiro que não implique em reciprocidade, "matando aquele que não matou", o que ocorre no sacrifício e possibilita que "as lanças sejam colocadas de lado", sendo possível desse modo negociar e entrar numa reciprocidade positiva característica do dom. Anspach (2012) reflete a partir desse esboço analítico que essa antecipação presente no sacrifício que permite a saída do ciclo vicioso da vingança é a mesma presente no ciclo da dádiva, onde em suas palavras "dá aquele que vai dar".

Compartilhando os desenvolvimentos do ensaio sobre a dádiva realizado pelo MAUSS e incorporando a eles a discussão teórica sobre moral e reconhecimento presente em seus trabalhos anteriores (1989, 1996), o antropólogo brasileiro, Luís Roberto Cardoso de Oliveira dá um passo adiante na preocupação com o laço social como defendido por Caillé e Godbout. Para Cardoso de Oliveira (2004), os envolvidos nas trocas de dádivas não têm como intensão somente a criação de laços, mas também, sua minuciosa manutenção. Pensando neste sentido, o autor argumenta que a qualidade da relação é imprescindível na troca de dádivas, por isso quando negada em uma relação de trocas já existente, tal negação pode causar um grande abalo ou rompimento no laço social estabelecido e acarretaria em um insulto moral, uma negação da identidade do outro, o que pode não só encerrar a relação para sempre como causar danos ao self do ofendido ${ }^{3}$.

Ainda que muito reduzido o número de autores aqui citados enquanto debatedores e ampliadores do ensaio sobre a dádiva, esses autores foram os que mais me influenciaram diretamente e ampliaram o debate em torno da dádiva como discutida por Marcel Mauss. Apesar da influência desses autores na minha própria interpretação da troca de dádivas, gostaria de detalhar aqui como construí essa interpretação através de inúmeras discordâncias e concordâncias com a teoria desenvolvida por eles. Preferi não citar neste momento alguns outros autores de grande importância no debate da obra, devido a intenção de manter o foco na dádiva e não nos desenvolvimentos que foram realizados a partir do termo reciprocidade, o que em minha opinião constitui um outro viés de análise das trocas humanas que difere das questões propostas aqui. Os pontos de contato entre essas interpretações e ampliações do trabalho de Marcel Mauss serão discutidos no tópico seguinte.

\footnotetext{
${ }^{3}$ Self e "Eu", são usados com o mesmo sentido ao longo deste trabalho.
} 


\section{CONSTRUINDO UMA INTERPRETAÇÃO DA DÁDIVA}

Em primeiro lugar, para se construir aqui uma interpretação sobre a troca de dádivas ou o sistema de prestações totais, como chamou Marcel Mauss (1950/2003), é imprescindível explicar o que entendo enquanto dádiva ou dom. Em meu ponto de vista, esse fortemente influenciado pelas teorias dos autores citados no tópico anterior, a trocadádiva é uma forma não calculista, que age em nível pré-consciente, de estabelecimento de relações sociais. Impulsionada e regida pelas disposições do habitus das partes, manifestada através de uma relação dialógica pautada no reconhecimento e mantida por uma self decepcion, uma ilusão compartilhada entre indivíduo e sociedade, como argumentou Bourdieu (1996). Nela compartilha-se mais do que presentes, mas Egos, ou Self's, já que assim como Mauss (1950/2003) entendo o dom enquanto coisa-pessoa, uma coisa que leva consigo parte daquele que o deu.

Seguindo essa linha de pensamento, concordo com o argumento de Douglas (1990) sobre a não existência do dom gratuito, pois se a interpretação do dom feita por Mauss (1950/2003) era a de que se troca para criar vínculos ou fortalecê-los, o dom sem tal intenção não existe. Assumindo a inexistência dos dons gratuitos a partir da perspectiva de Douglas (1990), me oponho à dádiva pura e gratuita, defendida por Marshall Sahlins (1965) ao falar da reciprocidade na microesfera do parentesco, mas não descaracterizando as trocas entre pais e filhos enquanto não dádivas, mas sim atribuindo à elas o status de dádivas comuns, acompanhadas de retribuição, seja ela simbólica ou material, a curto ou longo prazo.

O ponto de vista defendido pela autora é importante, pois serve para ajudar a delimitar o que pode ser considerado uma dádiva ou não, no sentido proposto por Mauss (1950/2003). Um exemplo disso seria não considerar uma esmola enquanto uma dádiva, pois tal tipo de dádiva não tem como foco os vínculos sociais com um outro, logo o dom no sentido maussiano não existiria como tal, pois a coisa doada, sem a possibilidade da retribuição estaria esvaziada da substância do doador (ou hau como colocou Mauss se utilizando de um termo Maori).

Contudo, pensando no nível da "atuação profunda" (deep acting), como proposto por Hochschild (1983/2013), vejo o foco de doações como a esmola ou a doação de sangue, enquanto ações orientadas para uma autossatisfação, uma troca consigo mesmo, 
como uma dádiva entre o Eu e o Supereu da teoria freudiana, o que mostraria que a motivação deste tipo de ação reside na busca por reconhecimento do "terceiro" em um metanível (neste caso representado pelo Supereu enquanto instância psíquica das normas sociais), mas que pode também ser encontrado externamente através do "terceiro" enquanto observador que valida a ação. Ainda que não tenha me dedicado muito a essa reflexão, teoria semelhante sobre "o terceiro", pode ser encontrada em Anspach (2012) quando o mesmo fala sobre "o enigma do terceiro".

A base da minha interpretação sobre a prática da dádiva é pensada a partir do que Bourdieu definiu enquanto habitus, como

\begin{abstract}
Regra feita homem ou, melhor, um modus operandi (...) que funciona em estado prático segundo as normas (...) sem ter estas normas na sua origem: é esta espécie de sentido do jogo (...) que faz com que se faça o que é preciso fazer no momento próprio, sem ter havido necessidade de tematizar o que havia que fazer, e menos ainda a regra que permite gerar a conduta adequada (BOURDIEU, 2000, p.23).
\end{abstract}

Godbout em uma pequena passagem em um dos seus textos toca em um dos pontos que me chamaram a atenção não só para a "atuação profunda" presente na dádiva, como para o conceito de habitus como central no entendimento de sua prática, diz o autor: “a 'verdadeira' dádiva é um gesto socialmente espontâneo, um movimento impossível de captar em movimento, uma obrigação que o doador dá a si mesmo, mas uma obrigação interna, imanente" (GODBOUT, 1998. p. 9).

Ao meu ver todos os autores citados no tópico anterior situaram a dádiva fora do mercado e do estado, entre o individualismo e o holismo, em especial os membros do MAUSS que conseguiram retratar com grande densidade teórica as relações do dom com os paradigmas economicistas, ainda que discorde sobre o dom ser um terceiro paradigma, concordo com eles no que diz respeito ao dom enquanto um híbrido entre dois paradigmas e sua existência nos dois, ainda que as vezes antagônica e as vezes dialógica.

No que diz respeito ao tema da incerteza enquanto forma de distanciamento da obrigação e fonte de confiança necessária do "dar, para que o outro dê" como existente na obra de Godbout e Anspach, carece um pouco da discussão feita por Bourdieu sobre o fator do tempo entre as dádivas, por isso proponho trabalhar juntando a interpretação dos dois. Ambos os autores concordam que a "veracidade" do dom, depende de como o primeiro doador recebe a retribuição, como colocado pelos autores, é necessário criar zonas de incertezas (GODBOUT, 1998), criando uma ilusão (BOURDIEU, 1996) de que 
este não está sendo retribuído, mas sim presenteado, pois só assim é possível dar enquanto retribui e ganhar enquanto está sendo retribuído. Para que essa "atuação profunda" ocorra com sucesso, é necessário um determinado tempo entre o dom e o contra-dom como argumentou Bourdieu, para que de certa forma (aqui em um exemplo caricaturalmente supérfluo), uma das partes "esqueça" o que deu e acredite ganhar ao ser retribuído. Se de alguma forma esse esquema não é realizado perfeitamente, "reconhece-se o que não se deve reconhecer" como colocado por Asnpach (2012) e que é justamente, ao meu ver, o que Bourdieu (apud Aspach) queria dizer com "a lei do interesse que governa o mundo não é bonita de se ver", pois quando se "reconhece o que não se deve reconhecer" ou seja o contra-dom, o mesmo perde o seu sentido como dom, já que passa da beleza da gratuidade ao horror da obrigação.

Em casos como esse em que a retribuição perde sua máscara de dádiva e passa a ser vista como resposta, identifica-se um abalo no vínculo social que une as partes envolvidas na troca, muitas vezes perceptível na qualidade do relacionamento. Se por algum motivo o doador, suspeita ou tem certeza de que não haverá retribuição isso pode ser interpretado "como uma recusa a responder e uma espécie de gesto de desprezo ou como uma evasiva provocada pela impotência ou covardia, que lança na desonra" (BOURDIEU, 1996. p.15), uma negação da identidade do doador enquanto pessoa digna de retribuição, aquilo que Cardoso de Oliveira (2004, 2011) chamou de insulto moral.

Resumindo, o que até então foi discutido aqui, acredito que as prestações totais são a forma primordial de construção de vínculos sociais entre os homens e os seus “outros" (deuses, homens, natureza e etc). Para a formação, manutenção e eliminação desses vínculos são feitas dádivas, doações aparentemente desinteressadas de retribuição, a coisa dada carrega em si parte daquele que deu, de certa forma ela é um gatilho emocional para aquele que recebe, uma lembrança constante do outro, uma extensão do seu "Eu" (o que Mauss chamou de hau e em sua interpretação implicava uma ligação espiritual entre coisa e pessoa). Ao estar vinculado a outra pessoa através de uma relação de troca de dádivas, me compartilho com ela, pois ao dar, me dou, assim eu e "o outro" nos tornamos parte um do outro. Contudo, para que o outro troque comigo, é necessário que ele me reconheça enquanto pessoa digna de contato, alguém com quem ele queira e possa estabelecer uma relação de confiança.

A confiança na retribuição é alimentada através de uma "atuação profunda" responsável pelo autoconvencimento do doador de que ele deu sem desejar uma contrapartida, de que mesmo negada a retribuição, não haverá problemas. Dessa forma 
quanto maior a incerteza do contra-dom, mais o doador se liberta do "interesse" e mais o receptor se liberta da obrigação, desta maneira a única obrigação com a dádiva parece ser a de libertar e ser libertado. Para isso, o tempo entre o dom de abertura e o contra-dom é essencial, pois de acordo com o contexto e do que foi doado, pode ser necessário mais, ou menos, tempo para o sucesso da "atuação profunda" enquanto manobra de convencimento inconsciente do self.

Uma vez que a relação entre as duas partes é iniciada de maneira positiva (quando há o contra-dom), é necessária uma manutenção cautelosa das trocas, ou seja, com a qualidade da relação, uma vez que abalos neste tipo de ligação podem ser cruciais para preservar o futuro das trocas entre as partes. Quando algum dom de abertura é negado ou a relação é rompida, incorre-se no insulto moral que representa a recusa do outro enquanto um igual digno de reconhecimento enquanto retribuição. Todas as relações de trocas de dádivas são mediadas por um terceiro, ainda que esse possa ser materializado na forma de pessoas e grupos ou simbólicos como deuses e normas sociais.

Tentei deixar claro, como interpreto as prestações totais, pois acredito ser crucial para o entendimento da análise feita neste ensaio, já que as mesmas em minha hipótese, são responsáveis pela formação das relações sociais no campo pesquisado e por isso necessárias para melhor entendê-lo. No tópico seguinte descrevo o contexto em que se deu a pesquisa.

\section{O CONTEXTO LOCAL}

O pavilhão feminino faz parte de um antigo complexo penal do qual agora funcionam apenas três pavilhões, dois masculinos e um feminino. A unidade masculina e a feminina ainda que vizinhos e pertencentes ao mesmo complexo, funcionam como unidades independentes e cada um possui um encarregado ocupando o cargo de diretor ou diretora.

A prisão feminina é composta por treze celas de convivência, uma cela berçário, três celas para sanções disciplinares e duas celas especiais. As celas na prisão ainda que pequenas foram feitas para abrigar de duas a três internas, no entanto acabam abrigando entre cinco e sete. Além das celas, a unidade conta com uma enfermaria improvisada, uma sala para atendimento médico pediátrico, uma sala para assistência social, um espaço para aulas e cultos, uma cozinha, sala de revistas, um alojamento para as agentes 
penitenciárias, lavanderia para as internas e uma sala para a diretora. A unidade é bem pequena se comparada às unidades masculinas espalhadas pelo estado do $\mathrm{RN}$, mas ainda é o principal local de cumprimento de pena em regime fechado para as mulheres. Se estima que $75 \%$ das internas estão lá por tráfico de drogas e suas 74 vagas (68 segundo relatório do CNJ de 2013) comportam população em torno de 96 a 106 mulheres. Esse número nos mostra que a unidade detém mais internas do que foi feita para abrigar e isso obriga novos ajustamentos por parte da equipe dirigente, assim como das internas entre $\mathrm{si}^{4}$.

Devido à falta de orçamento e comprometimento do estado local para com o sistema penitenciário, não só a segurança e os serviços nas unidades são prejudicados, mas os próprios bens necessários a manutenção da dignidade humana daquelas que são suas internas ${ }^{5}$. Quando ingressas na ala feminina do CPJC, o único bem recebido, quando disponível, é uma camisa branca e um short azul que constitui o fardamento. Não é permitido a circulação de dinheiro no pavilhão, o dinheiro das internas fica em uma pasta aberta em seu nome na direção da unidade. Nada como sabonete, escova de dentes, toalhas ou absorventes são entregues pela instituição, ficando esses as custas da própria apenada. A água bebida nas celas de convivência é a da torneira de uma única pia existente por cela. A situação é tão crítica que nem o papel higiênico das celas é fornecido pelo estado. As más condições de alojamento e a insalubridade do local é tanta que se juntam ratos, baratas, mosquitos e outros tipos de pragas nos arredores e dependências da instituição. É importante destacar aqui que o fardamento das internas foi conseguido pela direção e equipe de agentes através de doações. As raras ocasiões em que toalhas, fraudas, lençóis e itens de higiene, são entregues ás internas se dão através dessas doações provenientes de grupos religiosos, projetos sociais e das agentes penitenciárias que trabalham no pavilhão.

Levando em consideração a situação em que as internas sem auxílio externo são obrigadas a viver, muitas nem saem de suas celas e talvez por isso seja fácil compreender porque as minhas interlocutoras falam tanto de interesse, "amor por interesse", "amizade

\footnotetext{
4 Os números locais e de pesquisas quantitativas, feitas por instituições governamentais, variam consideravelmente entre si. Para além dos números no meio do ano de 2015, já posterior à época da pesquisa, algumas reformas foram feitas o que pode ter alterado ainda mais os dados aqui presentes.

${ }^{5}$ Faz-se importante notar que isso também um reflexo do próprio desinteresse social em destinar verbas para a área penitenciária quando que em comparação a pressão popular por mais dinheiro na saúde, segurança pública e educação. Da mesma forma o pouco dinheiro ainda destinado ao sistema não consegue ser totalmente utilizado devido à falta de estrutura para receber políticas públicas de investimentos a nível federal.
} 
por interesse" e assim sucessivamente com outras formas de relacionamento. Como a grande maioria não recebe auxílio, aquelas que recebem algo, estão sempre em estado de alerta pois acreditam que o único motivo de outra interna se aproximar delas é por interesse (com poucas exceções das amigas de igreja e projetos). Contudo, as internas mais afortunadas, que recebem diversos bens de fora da prisão, se situam hierarquicamente privilegiadas uma vez que se tornam o centro das atenções daquelas que anseiam por doações. Muitas dessas internas se responsabilizam pelas outras, e se comprometem a ajudá-las com o que recebem. Ao comunicarem isso à equipe dirigente, a direção faz o possível para transferir a interna necessitada para a sala da amiga. Olhando por esse lado, também não nos espanta os enormes boatos sobre amores por interesse que as internas tanto comentam e que essas mudanças de cela sempre deem o que falar no pátio do pavilhão. Nós tópicos a seguir pretendo descrever como essa situação chegou a se estabelecer na prisão feminina do CPJC.

\section{DO MERCADO A DÁDIVA}

As coisas nem sempre foram como tem sido nos últimos quatro anos, antes do ano de 2011, o dinheiro era permitido dentro do pavilhão, assim como os bens pessoais como roupas e utensílios de beleza. Durante esse período anterior a 2011, a organização social do pavilhão era diferente, pois existiam internas que, possuindo muito dinheiro, pagavam pela mão de obra de suas colegas de reclusão. Serviços como lavagem de roupa, limpeza da cela, tratamento de beleza, e até mesmo sexo, eram comprados com dinheiro. No antigo modus operandi das trocas dentro do pavilhão imperava a lógica do mercado marcada pela impessoalidade da troca imediata e a reprodução estrutural das classes econômicas existentes fora do mundo intramuros, como é possível ver no relato de Sharon ${ }^{6}$ :

Eu não tenho habilidade para o lar, eu fui criada pela minha avó, eu sou uma patricinha que tendeu para o crime e tou aqui. Eu não sei lavar roupa, eu não sei lavar banheiro, eu hoje sou obrigada a fazer isso! Porquê? Porque eu não posso colocar grana aqui dentro pra pagar. Eu recebia da minha habilidade com estética. Eu fazia cabelo, fazia unha, fazia meu artesanato, ganhava grana e acabava beneficiando outras pessoas com a minha grana, pagando pra fazer minha faxina, lavar a minha roupa. Hoje isso acabou, não existe mais por causa

\footnotetext{
${ }^{6}$ Todos os nomes das interlocutoras aqui citados são fictícios, pseudônimos criados na tentativa de preservar suas identidades.
} 
dessa nova regra da proibição de dinheiro aqui dentro do presidio. E isso acabou com uma estrutura financeira de um monte de gente, tipo assim: tinha presa aqui que lavava as roupas de outras presas pra juntar um dinheirinho a semana toda pra no fim de semana mandar dinheiro pros filhos que deixou com a sogra ou com a mãe em casa, hoje essa presa não pode mais lavar roupa para as outras, porque tem pessoas de vários poderes aquisitivos aqui dentro, tem gente que pode pagar!

A entrevista de Sharon me foi concedida em agosto de 2011, pouco tempo depois da implementação de regras mais rígidas no controle das internas, como a proibição de dinheiro, roupas próprias e utensílios de beleza. Neste pequeno trecho acima citado percebe-se a extensão do mercado interno da prisão e como o dinheiro circulava, inclusive, fora dos muros da prisão. O dinheiro neste caso seria aquilo que Rafael Godoi (2010) classificou como "vaso comunicante", pois sua entrada e saída estabelecia não só uma ligação entre o intra e o extramuros, mas uma relação dialógica entre os dois. Outro fator importante a ser notado aqui é que aparentemente o dinheiro faturado dentro da prisão, era gasto mais fora dela, em compras ou em auxílio de algum parente ${ }^{7}$. Tal configuração, permitia inclusive a algumas internas continuar provendo seus filhos de dentro para fora dos muros, mantendo uma relação em que a prisão era a origem do dinheiro e o seu lar, fora dela, o destino.

Quanto a razão para a proibição da circulação do dinheiro dentro do pavilhão, Sharon tentou me explicar de acordo com o que ela sabia:

\begin{abstract}
Algo que atrapalhou muito nosso dia-a-dia foi o problema com o dinheiro, porque houve uma revista e foi encontrado o valor de dinheiro na roupa de uma pessoa e parece que drogas. Eu não sei dizer, porque eu não tava presente, mas ela justificou dessa forma: porque foi encontrado droga com dinheiro e por causa de ter encontrado isso, foi proibido dinheiro.
\end{abstract}

Sendo verdade, ou não, a história contada por Sharon, fato é que toda a organização social do presídio foi abalada pelas novas regras implementadas e é claro, a proibição do dinheiro parece ter sido uma das principais dentro delas. Com a proibição da circulação do dinheiro e de utensílios de beleza, as internas que antes gozavam de uma qualidade de vida diferenciada em virtude das empregadas e regalias, passaram a se encontrar no mesmo nível daquelas que antes trabalhavam para elas. Contudo, tal situação não durou muito e aparentemente prejudicou mais as prestadoras de serviços do que suas antigas patroas.

\footnotetext{
${ }^{7}$ Interessante pensar que estas mesmas compras retornariam a prisão em seguida, o que mostra o tamanho do alcance do dinheiro enquanto moeda.
} 
Com a proibição, é verdade que as antigas patroas agora tinham que pôr "a mão na massa”, já que não tinham mais como pagar suas empregadas, contudo, aquelas que só possuíam fonte de renda dentro do pavilhão estavam falidas, sem poder ajudar nem aos seus parentes e nem a si próprias. Com a "pobreza" geral instaurada no pavilhão, materiais básicos para se manter uma qualidade de vida digna, como absorvente, papel higiênico, sabonetes ou até um miojo, passaram a ser os principais objetos de desejo dentro da prisão. Contudo, uma vez que a troca utilitária do dinheiro havia sido abolida, outro tipo de relação de troca se fortaleceu e, ao meu ver, acabou por dominar o pavilhão, a troca de dádivas.

\section{A TROCA DE DÁDIVAS EM UMA PRISÃO DE MULHERES}

Estima-se que um número significativo de internas não recebe visita social e ainda que mais da metade receba, só uma parte desses visitantes leva algum tipo de bem material para uma interna na prisão, os as vezes chamados "jumbos" podem levar, comida, roupas íntimas e utensílios de higiene pessoal. Ainda que esse tipo de pacote seja um "vaso comunicante", percebe-se que diferentemente do dinheiro ele não é dialógico e sim unilateral, pois parte de fora para dentro do presídio, como uma via de comunicação externa-interna, ao que antes através do dinheiro existia uma relação interna-externainterna.

Nos dias atuais, ainda é possível o ganho monetário dentro do pavilhão, entretanto, diferente do que havia no passado, esses ganhos agora só podem ser obtidos por meios institucionais, o que significa: trabalho para o governo ou em projetos sociais. Contudo, o trabalho institucionalizado possui uma baixa remuneração e essa remuneração não pode ficar com as internas, sendo depositada nas pastas específicas que se encontram na direção. Com essa manobra, as internas não poderiam mais comprar o serviço das outras, ou usar o dinheiro como influência dentro da unidade. Dos usos desse dinheiro acumulado na pasta, só é permitido a transferência para algum visitante cadastrado ou em caso de necessidade, para alguma agente penitenciária. Observei que esse dinheiro com muita frequência é utilizado para compras de remédios ou material de higiene e muitos são os casos em que por falta de visitantes cadastrados, as agentes penitenciárias que se responsabilizam por sair, comprar e entregar o item as internas. 
Cheguei a pensar que com a saída do dinheiro da unidade, seria fácil interpretar que bastaria adotar outra moeda de troca como cigarros, absorventes ou miojo, o que de fato acontece, mas que nem de longe, acontece de maneira tão simples como eu pensava. As trocas envolvendo esses tipos de bens pessoais adquiriu complexidade quando foi instituído pela unidade um número limite o qual cada interna pode ter deles, como mostra o exemplo da lista que adquiri com a direção do pavilhão:

Kit de material de higiene pessoal:

- 01 sabonete colorido

- 01 pasta de dente em gel (colorida)

- Uma escova de dente (cabo curto)

- 01 desodorante roll-on sem a bolinha (transparente)

- 04 rolos de papel higiênico

- 01 shampoo (em frasco transparente)

- 01 absorvente (pacote lacrado com até 24)

Como é possível ver no exemplo acima, ainda que seja uma pequena parte da lista, a entrada dos itens na prisão é extremamente controlada, em tipo e número. As "feiras" ou "jumbos", são entregues uma vez por mês, itens adicionais podem ser entregues nos dias específicos para tal, contudo, a interna não pode exceder o número dos itens específicos determinados pela direção. Dessa maneira, se torna difícil trocar o pouco que se tem, por serviços ou outros objetos desejados dentro da prisão, uma vez que ao trocar, a interna poderia ficar sem ter para si própria. Como se não fosse suficiente, agregou-se às regras estabelecidas uma sanção disciplinar para aquelas que trocarem objetos entre as celas, aumentando ainda mais a dificuldade de interações mercadológicas no seio da prisão.

Tal endurecimento em relação a circulação de dinheiro e outros bens dentro do pavilhão fazia parte da estratégia implantada em 2011 para a redução do comércio informal organizado pelas internas, com a intenção de coibir o poder de influência de algumas internas, assim como uma enorme rede trocas de materiais ilegais como drogas, celulares, armas caseiras e etc. Contudo, esse movimento, ao meu ver, ainda que efetivo no combate do comércio ilegal, tornou possível uma maior aproximação entre as internas, pois essas passaram a compartilhar mais do que trocar. A esse compartilhamento, me 
refiro ao ato de dar àquelas mais próximas, parte do que é seu, sem cobrar retorno, criando um vínculo de confiança de que quando a hora chegasse, também iriam receber a doação da colega em questão. O que na prática se torna o "dar para que o outro dê" ou "dar àquele que vai dar", como argumentado respectivamente por Godbout (1998) e Anspach (2012). Devido a mudança do contexto local na restrição de uma moeda de troca, a dádiva encontrou espaço para prosperar em meio as novas relações que se viam necessárias dentro do pavilhão feminino do CPJC.

\subsection{Do ato de dar}

O aspecto de uma dádiva "verdadeira", enquanto espontânea e gratuita através da aparente doação, me chamou atenção a partir de alguns momentos em minhas interlocuções com as internas. Em um dos casos, enquanto conversava com a interna Lívia, perguntei qual o momento em que elas trocavam suas coisas, uma vez que era proibido passar coisas de uma cela à outra e ela me olhou com espanto e disse "trocar!?" e me corrigiu logo em seguida “dar!”, correção devidamente feita, tenta me explicar como fazia:

\footnotetext{
Se eu tiver que dar algo a você eu tenho que dar antes do tranca, [a partir deste ponto me conta em tom de cochicho] por que se elas virem passar, você fica de castigo, a cela toda! 3 dias! E nesse tempo você fica sem visita porque normalmente pega a quarta ou o sábado que são dias de visita. A gente divide ai dentro. Elas [as agentes] acham que é comercializar, mas a gente divide.
}

Como visto no trecho acima, é enfatizado o fato de dar e dividir, onde aparentemente não se pensa em cobrança, contudo em relatos, como o da interna Andressa citado abaixo, é possível observar não só a importância da incerteza presente no tempo entre os dons para que a retribuição seja tomada enquanto um novo dom (BOURDIEU, 1996), mas também a decepção sentida por uma não retribuição percebida como ato de desconsideração (CARDOSO DE OLIVEIRA, 2004).

Eu sou uma pessoa que eu gosto de ter minha amizade assim: eu gosto de ajudar com o pouco que eu tenho, mas já fica diferente porque tem umas que eu ajudo, mas tem umas que não me ajuda. Pronto, se a minha mãe vinher e trouxer duas fardas e a outra pessoa não tiver, eu dou uma, se minha mãe traz um biscoito e a pessoa não tiver, eu divido, mas se aquilo meu se acabar já tem delas que não me dá. Aí fica difícil. É por essas coisas que eu também nem tenho saudade da vida lá no pátio. 
Nos relatos apresentados, as internas contam como dão em solidariedade, contudo, é notável que se deseja que esse ato de dar seja reconhecido, inclusive, como algo espontâneo para que a outra saiba que ela deu de bom grado, porque é uma pessoa generosa, porque é amiga. Dessa maneira, observa-se uma passagem daquilo que Allain Caillé chamou de "sociabilidade secundária" onde "a funcionalidade dos atores sociais que conta mais do que sua personalidade" para uma "sociabilidade primária", onde "as relações entre as pessoas são tidas como mais importantes ou como devendo ser mais importantes [...]. Esse registro é o da família, do parentesco e da aliança, da amizade e da camaradagem" (CAILLÉ apud ANSPACH, 2012. Pág. 74). É pelo tornar-se amiga que se espera que em uma situação de dificuldade haverá alguém para fazer o necessário em auxílio. Partindo deste ponto de vista, de como se procura "dar" dentro do pavilhão percebe-se a importância do foco no elo social nas dádivas, uma vez que essas mulheres buscam dar para estabelecer um vínculo de amizade para que um dia a amiga também dê.

\subsection{Do interesse no lucro}

Enquanto se aproximar e construir relações de amor ou amizade se torna a maneira mais rápida e segura de receber dádivas, aumentar o seu grupo de interação e a partir disso subir na hierarquia interna da prisão. Também se torna o principal fator de desconfiança e fofocas na unidade, onde a menor cortesia social pode ser uma suspeita de "interesse" o que pode ser exemplificado pelos dois relatos seguintes:

Existe inicialmente toda uma assim, uma solidariedade, uma solidariedade que dura até o instante que você tem dinheiro pra manter seu luxo pra manter sua cadeia, se você não tiver nada, todo mundo pisa na tua cabeça, você é altamente humilhada dentro da cadeia, se você não tiver alguém que mande suas compras, alguém que mande sua alimentação, você é espinzinhada dentro da cadeia, você é desconsiderada. Ou você é avião né? Ou você é laranja dos outros, que laranja aqui na cadeia é o cara que vai segurar a parada da droga da outra, o celular da outra, aí você tem uma consideraçãozinha, ou você é aquela viciada que é a dona do passo. Se você vem pra cadeia sem nada ou você não é nada disso, você é altamente humilhada (Maressa).

Aqui dentro você só vale o que você tem entendeu? Se você tiver suas compras você vale suas compras e se você não tiver, você não vale nada, entendeu como é? Aqui tem amor Miojo, tem amor pudim, tem amor cigarro e outros tipos de amor que é tudo por interesse. É isso, é esse amor, elas não ficam por gostar, elas ficam por interesse. A mesma coisa é a amizade, muitas atrai você na amizade, só que num é amiga delas, elas tão atrás de alguma coisa que você tem entendeu? (Lívia). 
A partir do que foi descrito por Maressa, é possível observar que o auxílio externo, agrega status às internas que os possuem. Desta maneira engendra-se então um marco de distinção entre aquelas que não tem nada e aquelas que tem. Colocando desta maneira, os bens pessoais como uma condição de existência dentro do pavilhão, uma vez que segundo a lógica local "você é o que você tem", como descrito por Lívia, relega-se àquelas que "nada tem” à uma condição marginal de existência. A partir desta observação é possível supor que todo o pavilhão é perpassado por trocas materiais e simbólicas, onde a condição de existência referida no relato das internas diz respeito à capacidade de participação social nesse "mercado de bens".

O discurso sobre o interesse aparece de forma hegemônica nos relatos das minhas interlocutoras, revelando o lado obscuro do interesse no ganho, uma racionalização das relações de dádivas, ou como diria Godbout (1998), uma perversão da dádiva. De acordo com o discurso aparente, algumas internas estabeleceriam relações com o intuito de receber aquilo que a outra tem ou pode vir a ter. No ponto de vista local e que foi magistralmente resumido por Maressa e Lívia, as suas riquezas (aqui enquanto posses e quantidade de auxílio de visitantes que recebe) determinaria sua posição social e qualidade de vida durante a pena de prisão e o interesse regeria todas as formas de interação social entre aquelas que "tem" e aquelas que "nada tem". Ainda que as sujeitas da minha pesquisa pareçam realmente acreditar que suas interações são movidas puramente pela lógica mercadológica pautada no interesse, o que vi na prática cotidiana e em suas histórias foi algo bem diferente. Como, por exemplo, a história de Raysa.

Raysa é uma interna que namorava a cerca de onze anos com Rosana que uma vez havia sido sua companheira de cela, mas que agora encontrava-se em liberdade. As duas continuaram a manter o relacionamento, mesmo sem a possibilidade de visitas constantes por parte de Rosana que havia mudado de cidade a trabalho, contudo em sua ausência sua irmã continuava a levar feira para Raysa em todos os dias permitidos. Com a distância e a crescente solidão na prisão, Raysa apaixonou-se por Mariana, que estava a poucos meses presa, em pouco tempo Mariana correspondeu as investidas de Raysa e ficaram juntas. Raysa então resolveu acabar tudo com Rosana e firmar seu relacionamento de vez com Mariana, mesmo estando presas, contudo, de acordo com as regras do presídio isso impediria que a irmã de Rosana continuasse a mandar sua feira, mesmo com a mesma tendo dito a ela através de carta "não vou te abandonar, você sempre será da minha família”. Ainda que Mariana receba também uma feira, levará algum tempo até que Raysa possa receber autorização de compartilhar com ela os itens enviados, como também as 
duas teriam que dividir tudo aquilo que mal dá para uma, já que uma interna não pode receber duas feiras.

Histórias como a de Raysa (contada por uma frustrada Mariana que tentava ajudar sua companheira devido a necessidade que ela estava enfrentando), mostram claramente uma lógica inversa a do interesse de lucro e retribuição instantânea aparente no discurso das internas, pois assumir a relação com Mariana e romper o vínculo com Rosana, só prejudicou sua qualidade de vida na prisão. Ainda que pelos olhos de outras internas possa vir a ser visto como "amor miojo", a ação de Raysa é uma estratégia contrária ao ganho e a favor do elo social. Seria incompreensível tomar o amor nesse caso como fruto do interesse, uma vez que o dom de abertura (enquanto expressão do sentimento), feito por Raysa em seu desejo de união com Mariana, é uma aposta incerta baseada na confiança e ao meu ver uma verdadeira dádiva.

\section{CONCLUSÃO}

Após descrever como pode ter se dado a passagem da hegemonia do mercado à dádiva, assim como debater sobre o discurso local de que o interesse de lucro gere as formas de interação social no pavilhão, gostaria de concluir com uma reflexão mais completa sobre a dádiva e as mulheres em situação de prisão no CPJC.

A dádiva depende de um terceiro, um mediador enigmático que pode estar em todo lugar e em lugar nenhum, pode ser o amigo ao lado ou a voz da moral no pensamento, este terceiro valida e confere reconhecimento, o reconhecimento de que se está sendo verdadeiro, sincero ao dar e ao não querer receber, está na linguagem, quando dizemos quase que indagando ao outro "obrigado?" e ele nos diz "por nada" negando não só a obrigação como o custo do presente. Ela sempre existiu no ambiente prisional estudado, ainda que em diálogo com o mercado da troca impessoal, uma vez que esse último perdeu espaço devido as normas institucionais, a dádiva ocupou quase todo o espaço. É inegável que há uma perversão da dádiva, "atores cínicos" em busca de objetivos específicos nas interações da vida cotidiana (GOFFMAN, 1959/2007), mas a dádiva nunca será uma boa opção àqueles que não estão dispostos a esperar e como já foi dito anteriormente, a dar. O interesse mercadológico existe dentro do pavilhão feminino, contudo, ele se encontra nos relacionamentos efêmeros, longe das histórias de amor e amizade que inundam as conversas no pátio do presídio. 
A dádiva por sua vez, está em cada amizade, em cada romance, no sorriso com a carta do familiar que chega, na solidariedade com a amiga que vai para o castigo, assim como na celebração com aquela que saí em liberdade. Troca-se tudo na prisão, como nomeou Mauss, são prestações totais, as visitas de uma passam a visitar a outra, o familiar de uma passa a mandar a feira da outra, a amiga que sai toma conta do filho da que ainda está presa. E há dons que não circulam como argumentou Godelier (1996), o presente de uma ex-companheira de cela que saiu em liberdade é uma prova disso, ele é diferente, é um amuleto, ele acumula mana, ou melhor dizendo, ele é um símbolo do relacionamento com aquele "outro", ao mesmo tempo um condutor emocional para com ele, porquê como argumentou Mauss “coisa e pessoa se misturam".

O dom encontra-se no reconhecimento da nossa existência por um "outro" que não é só “o outro", mas também o todo, pois não há dádiva maior do que o reconhecimento. Quem deseja reconhecimento o deseja como uma dádiva que o mesmo seja espontâneo e não uma obrigação normativa. Talvez a dádiva impere no pavilhão feminino por necessidade, mas não por uma necessidade utilitária, mas sim, a necessidade de se conectar, de quebrar a solidão e a mortificação impostas pela prisão e seu controle sufocante. Uma necessidade de ser reconhecida enquanto membro de algo maior, seja um casal, um grupo ou toda a sociedade.

É incontestável que o fato de se viver em uma "instituição total" tem forte influência na forma como essas mulheres conduzem suas vidas, da forma como foi descrito aqui foi possível perceber a influência exacerbada da equipe dirigente na interação social das sujeitas lá internadas. Quando uma nova normativa entrou em vigor e alterou significantemente não só como elas se relacionavam, mas como se sentiam. Gostaria de terminar este texto com uma citação de Godbout (1998) que reitera o que já foi dito aqui e responde bem a questão, do porquê a dádiva ser hoje, em minha opinião, a principal forma de trocas ou se preferir, doações, entre as mulheres do pavilhão feminino.

Por que se dá? Se admitirmos o que precede, a resposta é simples: para se ligar, para se conectar à vida, para fazer circular as coisas num sistema vivo, para romper a solidão, sentir que não se está só e que se pertence a algo mais vasto, particularmente a humanidade (...). Por isso eu dizia que a dádiva é o que circula a serviço do laço social, o que o faz aparecer, o alimenta. Desde os presentes para os amigos e familiares até a doação por ocasião de grandes catástrofes naturais, a esmola na rua, a doação de sangue, é fundamentalmente para sentir essa comunicação, para romper o isolamento, para sentir a própria identidade (GODBOUT, 1998. Pág.11). 


\section{REFERÊNCIAS}

ALVES DOS SANTOS, Leonardo. Emoção e penalidade: mulheres no Complexo Penal Dr. João Chaves em Natal/RN. Dissertação (mestrado) Programa de PósGraduação em Antropologia Social, Universidade Federal do Rio Grande do Norte, 2015.

ANSPACH, Mark Rogin. Anatomia da vingança: figuras elementares da reciprocidade. Tradução de Margarita Maria Marcia Lamelo. - São Paulo: É Realizações, 2012 - (Biblioteca René Girard).

BOURDIEU, Pierre. Marginalia. Algumas Notas Adicionais sobre o Dom. In: Mana, 2 (2), pp. 7-20, 1996.

BOURDIEU, Pierre. O Poder Simbólico. Rio de Janeiro: Bertrand, 2000.

CAILLÉ, Alain. Antropologia do Dom: o terceiro paradigma. Rio de Janeiro: Editora Vozes, 2002.

CARDOSO DE OLIVEIRA, Roberto \& CARDOSO DE OLIVEIRA, Luís R. Ensaios antropológicos sobre moral e ética. Rio de Janeiro: Tempo Brasileiro, 1996.

CARDOSO DE OLIVEIRA, Luís Roberto. Fairness and Communication in Small Claims Courts. PhD. Dissertation, Harvard University, Department of Anthropology, 1989.

Honra, dignidade e reciprocidade, em

Martins, P. H. \& Nunes, B. F (orgs.). A nova ordem social: perspectivas da solidariedade contemporânea. Rio de Janeiro: Editora Vozes, 2004.

Direito Legal e Insulto moral: dilemas da

Cidadania no Brasil, Quebec e EUA. Rio de Janeiro: Garamond, 2011.

DOUGLAS, Mary. Forward: No free gifts, in: M. Mauss. The Gift. New York: W. W. Norton, pp. Viixviii, 1990.

GODBOUT, Jacques. Introdução à Dádiva, In: Revista Brasileira de Ciências Sociais no 38, vol. 13, pp. 39-51, 1998.

GODELIER, Maurice. O enigma da dádiva. Lisboa: Edições 70, 1996. 
GODOI, Rafael. Ao redor e através da prisão: cartografias do dispositivo carcerário contemporâneo. (Dissertação de conclusão do mestrado em sociologia), Universidade de São Paulo, 2010.

GOFFMAN, Erving. (1959) A representação do eu na vida cotidiana: tradução de Maria Célia Santos Raposo, 14ª ed. / Petrópolis, Vozes, 2007.

HOCHSCHILD, A. R. The managed heart: commercialization of human feeling. Berkeley, University of California Press, $3^{\text {a }}$ ed. 1983/2013.

MAUSS, Marcel. Sociologia e antropologia. Título original: Sociologie et anthropologie. Introdução: Claude Lévi-Strauss. Tradução: Paulo Neves. São Paulo: Cosac Naify, 1950/2003.

SAHLINS, Marshall. On the Sociology of Primitive Exchange, in: M. Banton (org.) The Relevance of Models for Social Anthropology. Londres e Nova York: Tavistock Publications, pp. 139-236, 1965.

\title{
THE PREPONDERANCE OF DONATION'S EXCHANGE IN A WOMEN'S PRISON
}

\begin{abstract}
ABSTACT
This text is a result for the master's degree dissertation presented in March 2015, under the title "Emotion and Penalty: Women in the Criminal Complex Dr. João Chaves". The objective of the present work is to try to understand the reason for preponderance of the exchange-gift inside the women's pavilion of the CPJC and the importance of these exchanges in the organization and social interaction of the women who live there. Aiming that objective, it was necessary to recover Marcel Mauss's theory of the gift, as well as the later developments made by other authors. In order to proceed with the description of the field researched and its analysis, the light of the ideas previously presented, presenting the thesis of the passage from the market mercantilist exchange to the gift-exchange. Finally, the conclusion suggests a possible response to the domain of the exchange of gifts in relation to mercantilist exchange within the female wing of the Dr. João Chaves Penal Complex.
\end{abstract}

